\title{
The Dynamic Interplay Between Agent and Structure in the Film The Shawshank Redemption
}

\author{
Limanta, L.S. \\ Faculty of Humanities, University of Indonesia, Depok, INDONESIA \\ English Department, Faculty of Letters, Petra Christian University, Surabaya, INDONESIA \\ email: satya@petra.ac.id
}

"Hope is a good thing. Maybe the best of things. And no good thing ever dies."

\begin{abstract}
A social phenomenon in society or as represented in a film can be analyzed from many different perspectives. One of the theories that can be applied to do that is Giddens' structuration theory. It emphasizes on the duality of structure meaning that agency is inseparable from structure and both affect each other. It consists of three-tiered dimensions, namely the structure of signification, domination, and legitimation, and the interaction that agents carry out in the form of communication, power and sanction mediated by the modality of interpretive scheme, facility, and norm. This paper will analyze the interplay of agency and structure in the film Shawshank Redemption through the characters of Andy, Red, Brooks, Captain Hadley, and Warden Norton. The analysis result shows that the agents in the film indeed can make some changes on the structure, but actually they only reproduce or transform it.
\end{abstract}

Keywords: Interplay, interlocking, agency, structure.

\section{INTRODUCTION}

A social phenomenon can be seen and analyzed from various angles and by using some approaches. Senior high school students' fight, for instance, can be analyzed from family education, economic issue, teenager psychology, even from the state's policy system that might cause a social gap. The very phenomenon can also be approached from the power relation between the teenagers and parents, among peer groups, and between the students and the school officials, from representation and identity articulation perspective, or from other perspectives. In sociology, there are two main contrasting approaches, namely structuralism and functionalism on the one hand, which emphasize too much on the role of structure and even overlook the role of individuals or agents (Giddens, 1986, p. 1). On the other hand, in the tradition of hermeneutics and interpretive sociology, the role of individuals or agents are more dominant than that of structure (ibid.). Giddens' structuration theory tries to end the dichotomy (dualism) since for him the area of social study was mainly social practices that were ordered in certain space and time (p. 2). Giddens avoided dualism between structure and agency, as separate entities facing against each other. Instead, through his structuration theory he saw the duality of structure, namely that agent was a part of structure through whose actions s/he reproduced the structure although s/he could make some changes. The basic feature of the duality of structure is that "structures are constituted through action, and reciprocally how action is constituted structurally" (Giddens as cited in Bryant and Jary, 2003, p. 253). Thus, there was an interplaying relation between the two (Giddens as cited in Priyono, 2003, p. 18). This paper will analyze the dynamic interplay between agency and structure in the film The Shawshank Redemption (1994) applying Giddens' structuration theory.

\section{DISCUSSION}

Structuration theory has many elements that should be explicated to see how each element can clarify the relation between structure and agency. First, agency is defined as "capability of doing those things" and not as "the intentions people have in doing things" (Giddens, p. 9). Second, the requirement for someone to qualify as an agent is that $s /$ he has a reflective consciousness (reflexive monitoring of action), rationalization of action, and motivation of action ( $p$. 
5). In other words, s/he can give reasons for her/his actions when being asked to give explanation for the actions and when being asked s/he can also give a discursive clarification for the reasons (p. 3). Third, Giddens saw structure mainly as rules and resources (pp. 17, 23), where structure has a constraining power (through rules) but also gives opportunities or enables an agent to achieve her/his goal in her/his actions (through resources) (p. 25). Fourth, the concept of power is to be understood not only as the ability to say no (p. 32), but its implication is also the ability to say yes. Fifth, the dimensions of the duality of structure can be described in the following diagram (p. 29):

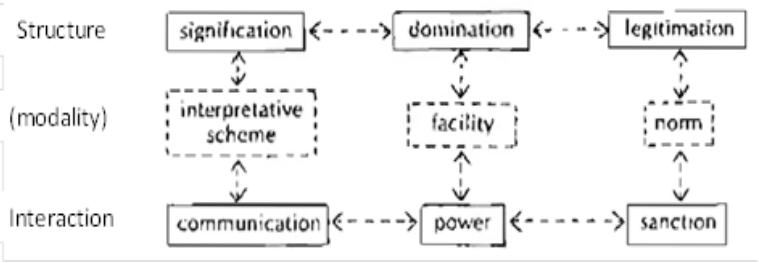

Structure has three main dimensions, namely signification, domination, and legitimation that are tightly connected and give effect to each other, and each dimension of the structure is related to interaction or action of the agent whose relation is mediated by the modality or resources. Signification structure provides a scheme for an agent to make meaning in her/his interaction in the social world through communication by utilizing a certain interpretive scheme. The domination structure is concerned with the production and exercise of power in the interaction which is derived from the control of facilities or resources (Lamsal, 2012, p. 115). While legitimation structure provides a standard of moral order through norms which results in a sanction if the agent fails to fulfil it. Thus, an agent's power will involve a domination which is determined by the extent of facilities s/he owns and utilizes, which in turn will give a sanction legitimated through the existing norms.

The structuration theory is very suitable to be applied in explaining the complexity of relation between structure and agency in a relatively established and stable society such as in a capitalist society. In this paper, I will try to apply Giddens' structuration concept explicated briefly above to explain the social phenomenon in a film. The film I choose to be analyzed is The Shawshank Redemption (1994). This film directed by Frank Darabont ranking number 1 with a rating of 9.2 according to The Film Spectrum (Fraley, 2011) told about a banker mistakenly sentenced to two life terms based on the proofs presented in the court that affirmed the suspicion that he killed his wife and her illicit lover although Andy Dufresne, the banker (starred by Tim Robbins), denied that he did it. In the prison Andy made friend with Ellis Boyd Redding who was called Red (starred by Morgan Freeman), and with an inmate who became a librarian in the prison, Brooks Hatlen. Meanwhile, the prison was led by Warden Norton (played by Bob Gunton) who was strict, corrupt, and hypocritical. As for the head guard, Shawshank prison was led by Captain Hadley. The relation among Andy, Norton, Hadley, Red, and Brooks will be interesting when it is explicated by structuration theory. The detail of the plot will be discussed in line with the analysis of the dynamic interplay between agency and structure in the film.

First, the agency of Andy is very outstanding in the prison Shawshank. If agency is defined as the ability to do many things consciously and purposively, many scenes can show Andy's agency. The first example is when Andy consciously offered a favor regarding financial management in relation to tax to Captain Hadley. This happened when some inmates did a volunteer work of roof tar-painting of a factory outside the prison. Upon hearing a talk among the prison guards that Captain Hadley got an inheritance from his brother who passed away but it left him some problems regarding tax, Andy gave an advice to donate it to Hadley's wife. Andy's act was very risky since being an inmate who should do his volunteer job he inappropriately eavesdropped and even interfered with Hadley's problem. Red, Andy's close friend, even warned him to keep focusing on his job since Red knew Hadley well as a cruel captain. With his legitimized power, Captain Hadley could have given a sanction by pushing Andy off the roof for not doing his job. However, as a banker who mastered financial problems very well, Andy could finally convince Hadley with sound arguments to accept his advice and even willingly gave Andy some bottles of beer to be given to his friends. Analyzed in the perspective of three-tiered structure as explained above, Andy could be said not to have significant power under the domination of powerful Captain Hadley. Nevertheless, due to the facility of knowledge about finance and tax regulations that Andy possessed, when he communicated with Captain Hadley applying the interpretive scheme of "financial expert" which then was realized and acknowledged by Captain Hadley, the resulting situation showed Andy's agency, namely Andy's advice was accepted and Andy's friends got beer as Andy requested (Screenshot 1 and 2). The unique incident of getting beer from a prison captain like Hadley as experienced by Red and his friends would never happen unless it was through Andy's agency. The impact of Andy's action was very unusual (inmates got beer from a prison guard), and the relation between Andy and his 
inmates was changed too. Since that day Andy's inmates respected and supported Andy, even the prison guards protected him from being bullied by Bogs (a fierce inmate) and his gangs. This example shows that even though Andy's agency can make a change on the relation of the inmates with the guards and among the inmates, it still needs the approval of Captain Hadley to accept Andy's offer and to grant his request. This shows an interlocking relation between agency and structure.

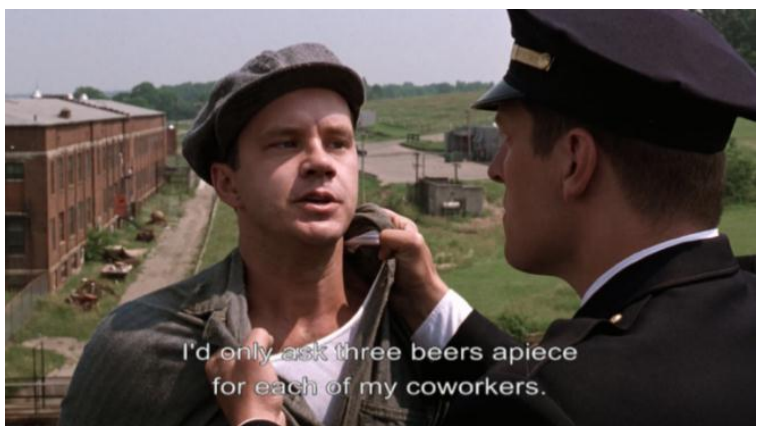

Screenshot 1. Andy's agency and the risk of being pushed off the roof

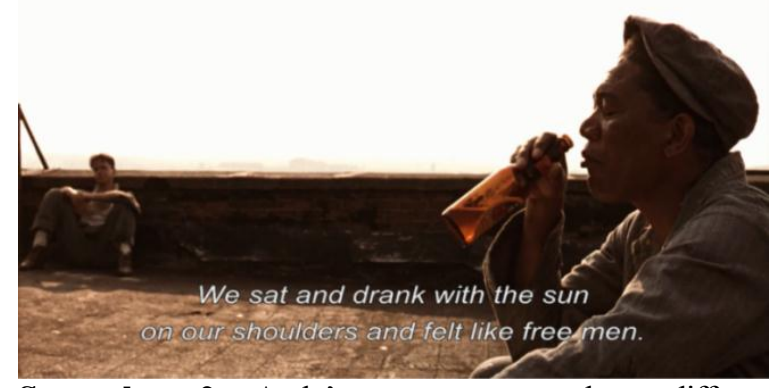

Screenshot 2. Andy's agency created a different atmosphere

The second example of Andy's agency was when Andy asked for some fund to add the book collections of prison library from Warden Norton. Of course, changing the structure in the prison regarding the library could be said to be impossible. Based on Brooks' experience (the inmate librarian) who had been imprisoned for more than 50 years and who had experienced six times of warden change, the request for fund to add the library book collections was never granted (Screenshot 3). However, with Andy's resource of financial and tax knowledge, which finally made Warden Norton also ask Andy for financial advice, Andy was allowed to write a letter to the Senate once every week (Screenshot 4). After 6 years of sending letters without break, Andy's request was granted. From the three-layered structure, it can be seen that Andy employs the resource of his relationship (facility) with the warden to get a permission to write letters to the Senate (domination) and the modality he applies to communicate is an interpretive scheme of "education" which finally gives power to him to get what he wants.

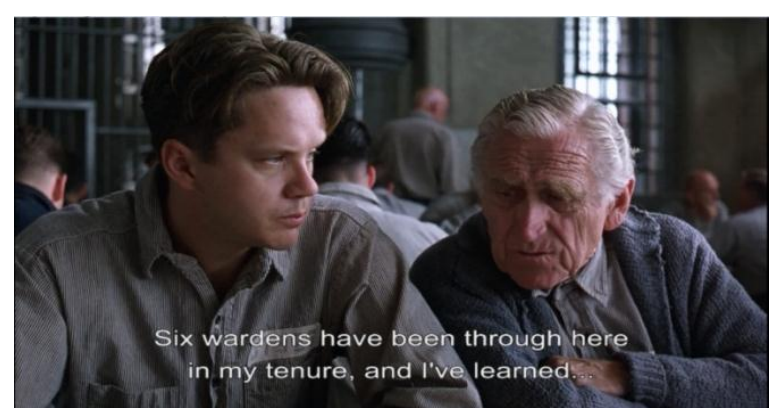

One immutable, universal truth: Not one of them ... wouldn't pucker up tighter than a snare drum when you asked for funds.

Screenshot 3. A very strong structure

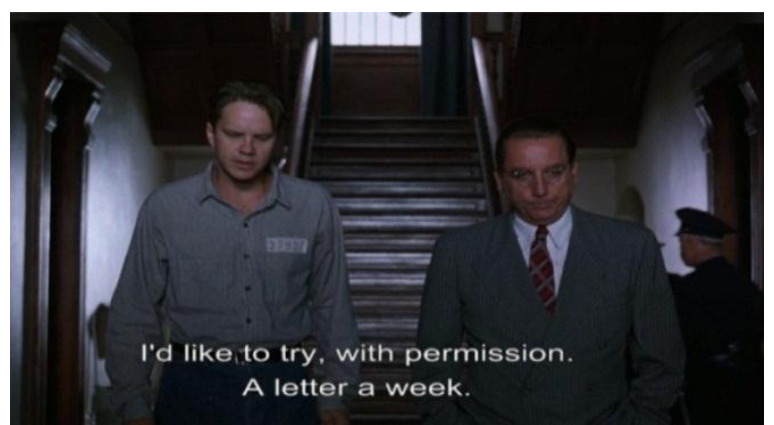

Screenshot 4. Strong structure and agent's negotiation with Warden Norton

As Warden Notron himself said that there were only three ways to spend the taxpayers' money for prison, namely for more walls, more bars, and more guards, which meant that a request for more books was sheer impossible. However, through his agency, Andy tried to negotiate with the Warden to get a permission to write letters. Actually, Warden Norton gave Andy a permission to write letters only to make him happy, but finally Andy's request was granted. This example shows that Andy's agency can change a part of the prison structure regarding the library although he needs to negotiate with the warden (representing the structure) to get the permission to write the letters. Thus, it shows that there is an interplay of Andy's agency and the prison structure.

The third example of Andy's agency vis-a-vis structure can be seen from how Andy breaks loose the grip of prison structure on Red as it did maleficently on Brooks (discussed below). A similar thing nearly happened to Red although not as miserably as what happened to Brooks, namely he wanted to go back and to live his old structured life in prison, where all things made sense to him (Screenshot 5). This thought was supported by Red's own statement that there was no way he could make it on the outside of prison and he thought of violating his parole by committing a crime. However, Andy broke the grip of the prison structure on Red by giving a thought about a choice a man could make. Andy convinced Red through his letter that hope was a good thing, and no good thing 
could ever die. Finally, Red made the choice to go and meet Andy, otherwise he would have ended up in prison all his life. In the room where Brooks carved on the wall "Brooks was here", before committing suicide, Red also carved a similar sentence next to it "so was Red", making a different choice to keep up living outside prison although the conclusion was unclear to him at that point (Screenshot 6).

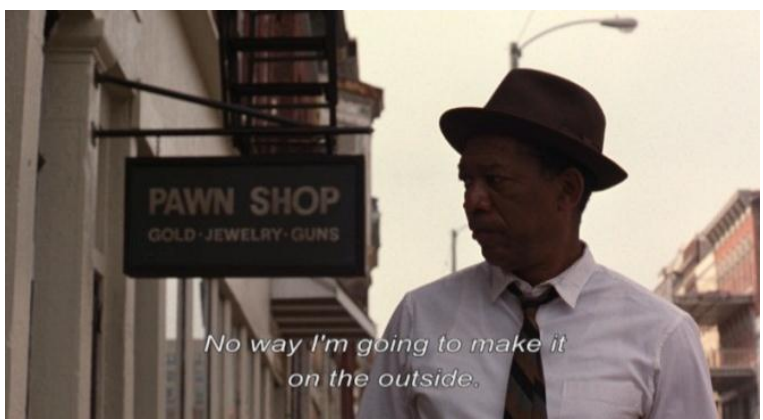

Screenshot 5. Prison structure's grip on Red after 40 years of being institutionalized

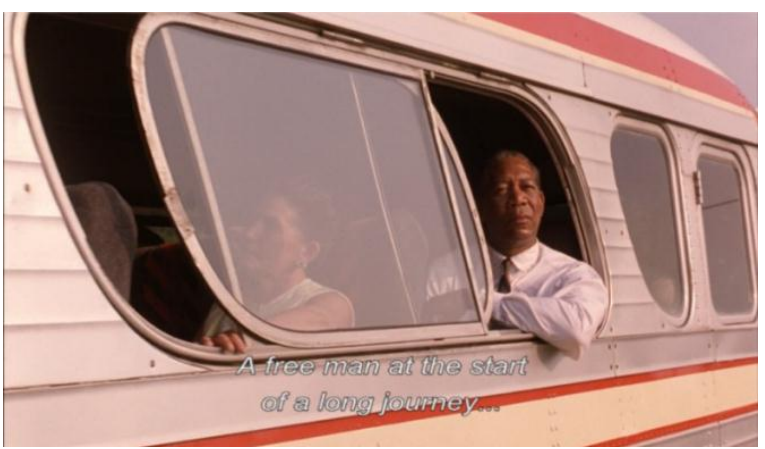

Screenshot 6. An inmate broke loose of prison structure's grip to start living a new life

The next example of Andy's agency can be seen after Andy got donations of books and some gramophone records and he played a record in the prison guard's office. Music in Shawshank prison was never heard, and Andy played the record and put it on the prison loudspeaker. It gave a stunning effect to all inmates as if it were a miracle for them (Screenshot 7), and it drove all the guards and Warden Norton furious. In this example, Andy's agency undermined the prison structure by doing something that was never done before in it. Furthermore, Andy played the record without asking permission from the guard or Warden Norton (who had power to determine what was accepted or what was not). Indeed, Andy's agency could make a change in prison, but it was only for a while. Nevertheless, it was not only a fancy change of habit in prison, but it gave such a profound impact to the inmates that Red made the following statement, "And for the briefest of moments, every last man at Shawshank felt free." However, Andy's action resulted in his being put in the hole (a stifling cell to give a punishment to disobedient inmates) for two weeks. This example shows how any effort of violating or undermining structure of domination (no matter how small it is) will result in a sanction, which is severe in Andy's case.

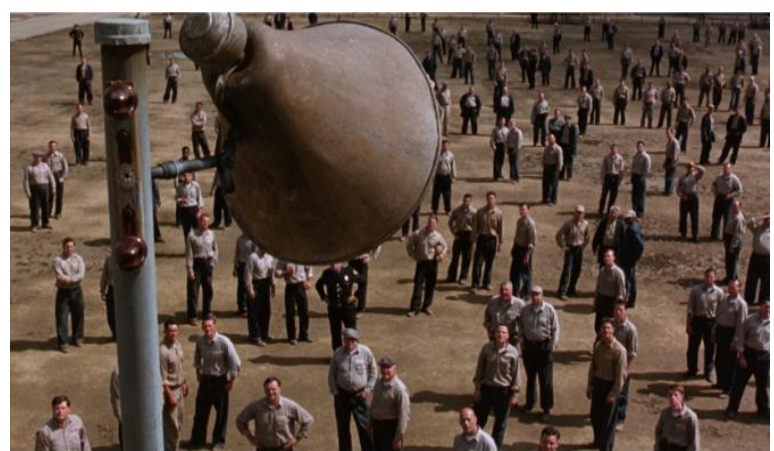

Screenshot 7. The stunning effect of music for the inmates

Although Andy's agency is clearly seen in the three examples above, but the role of structure in prison with the domination of the corrupt and hypocrite prison guards or abuse in law system is still very strong. This can be seen from the outset of court trial that sentenced Andy guilty. In court there has been a structure or system of "truth" verification based on the prosecutor's or lawyer's skill or intelligence in giving arguments that are supported with "proofs" to give consideration to the judge in making decision whether the accused is guilty or not. In this case, Andy was a helpless individual in dealing with such a structure. Then, when the prosecutor's arguments were making more sense although the truth was that Andy did not kill his wife and her illicit boyfriend, Andy was still sentenced to two life terms. From this perspective, it can be said that this film is a critic toward law and prison system in American society or even in any society elsewhere.

Later on when Andy had served his sentence for nineteen years, a young criminal named Tommy Williams happened to know another criminal called Blatch who boasted that he killed a professional golfer with his girlfriend and got escaped from his crime, he even felt proud that the guilt was put on Andy. The thing got worse when Andy tried to get justice from Warden Norton to trace Blatch for a retrial. The issue was that Warden Norton who was a corrupt officer wanted to keep Andy for life in prison for two reasons. First, he did not want to lose Andy to make illegal reports about his tax. Second, he was afraid that if Andy was free, his crime of not paying tax and of taking bribery would be revealed. He even ordered a guard to shoot Tomy Williams and created a story of Tony's escape for the murder. This example shows that the power invested in the prison structure or system can be easily abused and it is so deeply ingrained that it can determine people's behavior and life. When Andy met Warden Norton to follow up the 
story told by Tommy Williams, Warden Norton insisted on not finding the truth because of the two reasons mentioned earlier. When Andy persevered to get justice and pushed Norton by mentioning something about laundering the tax money, he was put in a solitary cell for a month (Screenshot 8). This cell effectively made someone suffer a lot so that Andy later on even admitted that he was guilty and quitted his idea of getting justice in line with the structure or system since he schemed his own way to find one. This example shows how the structure of the prison which gives a big power to the warden changes Andy's behavior and belief in his helplessness. It can be said that this example shows the interplaying working of prison structure and Norton's agency. Norton will not be able to exercise his agency if he is not taking the position of a warden in the prison structure.

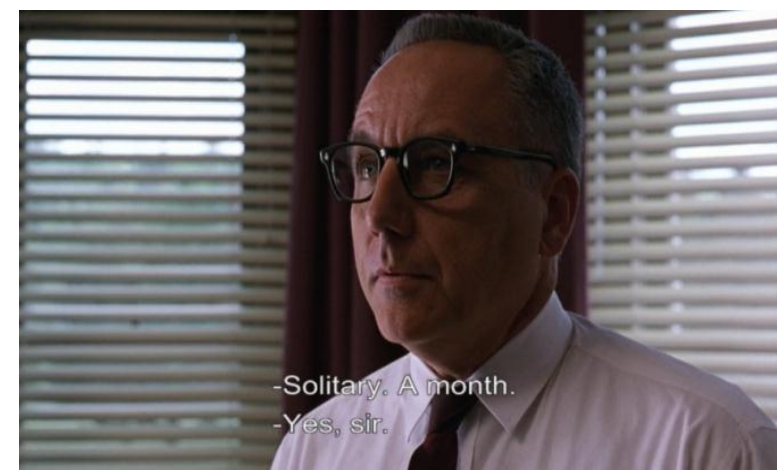

Screenshot 8. Norton made use of the prison structure as a warden with legitimate power to determine people's life and behavior

Second, the structure role was clearly seen when a new inmate who was sentenced some terms in prison got his first step into it. When coming to prison for the first time, there was a kind of "ritual" done by the other inmates or by the prison guards. In the film Shawshank Redemption the ritual was making a bet done by the inmates about who was among the "new fish" (their term for the new inmates) who would cry in their first night. Another ritual carried out by the prison guards toward the new inmates was putting their clothes off, showered them, poured louse powder on them, gave them prison clothes and the Bible. The structure in prison looked more dominant in the form of many rules that had to be obeyed by the inmates. Everything done by the inmates had to get permission from the guards, even when they needed to urinate. These rules were so deeply internalized in the inmates that even when Red was granted a parole and worked at a supermarket, every time he wanted to urinate he always asked for permission from the manager (which bothered him) and he said: "You don't need to ask me every time you need to go take a piss. Just go" (Screenshot 8). This was exactly what
Giddens (1986) said about the basic requirement of social systems: "The structural properties of social systems exist only in so far as forms of social conduct are reproduced chronically across time and space. The structuration of institutions can be understood in terms of how it comes about that social activities become 'stretched' across wide spans of time-space" (p. xxi). Further he said that the "fundamental concept of structuration theory" is routinization (p. xxiii). This is what Red experienced, which he called as being "institutionalized" for forty years (Screenshot 9).

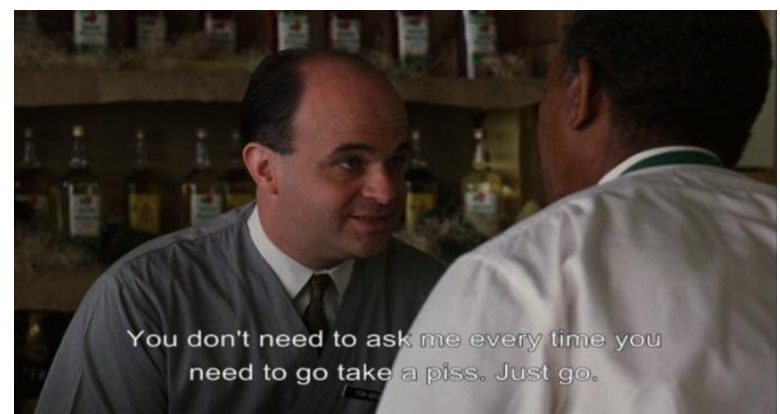

Screenshot 9. Institutionalization of structure

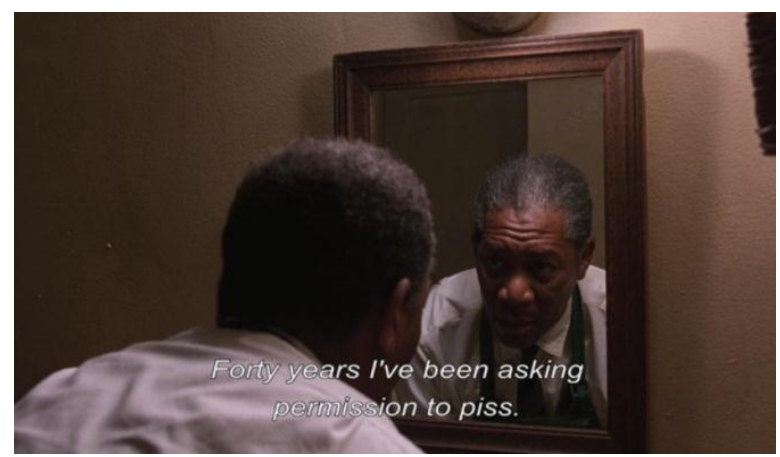

Screenshot 10. Routinization as the grounding of social life

In Red's case, although the role of structure was so strong, helped by Andy's agency, Red's agency appeared as he finally chose not to buy a gun and committed a crime again to be sent back to the prison. His consciousness and purposiveness enabled him to break loose from the grip of prison structure. This example shows again the interplay of Red's agency vis-a-vis prison structure.

The role of strong structure can also be clearly seen from Brooks' experience. After hearing that he was released, Brooks became depressed because he had been "institutionalized" by prison (a term first used by Red) for fifty years, meaning that he was so accustomed to living in prison that he could not know how to live outside it. Prison had created Brooks. He only knew how to live in prison. Since he could not adjust himself with a different fast-growing structure from that of the prison, he committed suicide. In prison Brooks was "somebody" who was useful for other inmates, but outside he was nothing. The statements made by Red were interesting: "But I tell 
you these walls are funny. First you hate them. Then you get used to them. Enough time passes... you get so you depend on them. That's 'institutionalized"'. This was why Brooks after being released and trying to adjust himself to live in the society as a free man could not stand it and finally committed suicide. In this example, Brooks' agency, that is the ability to do things by committing suicide, was the fossilizing powerful effect of prison structure that ripped him of the flexibility to live in a totally different new structure. Here, the interplay of Brooks' agency and prison structure resulted in an unfortunate and miserable event.

The next example of the dominant structure can be seen in the incident when Andy was beaten almost to death by Bogs and his gangs (called the Sisters). Bogs and his gangs were called the Sisters because they were gay. When Andy was forced by Bogs to do an oral sex and Andy embarrassed Bogs that he might bit it off, Bogs and his gangs beat him almost to death that Andy needed to be taken care of in the infirmary for a month while Bogs spent a week in the hole. The role of the structure was not only seen in the fact that Bogs' action was given a sanction because it violated the norm in the prison, but it was more strongly viewed from what Captain Hadley did to Boggs. Because of Andy's facility of financial knowledge and his service to almost all of the guards, the guards felt furious when Andy could not give a service to them due to the incident. What Captain Hadley and another guard did to Boggs after he got out of the hole was beating Boggs to stop him from bullying Andy in the future. Through the voice of Red, we are told that two things never happened again after that incident, namely the Sisters never bullied Andy anymore and Boggs never walked again (Screenshot 11). Later, Bogss was moved to a minimum security prison. This example shows the effect of Andy's service (thus his agency) toward the structure of domination in the form of power invested in Captain Hadley and the guards and how powerful the structure of domination is. In other words, there is an interplay of agency and structure in the incident.

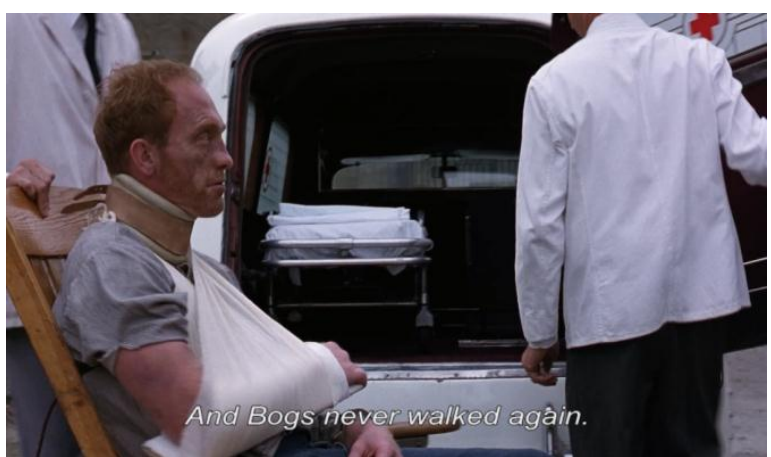

Screenshot 11. The effect of structure of domination to Boggs
Although prison structure looked dominant in the form of rules, it could also be seen as resources at the same time. This was clear from what Andy did by making use of his knowledge as a banker to give financial advice to almost all prison guards including Warden Norton. As has been discussed earlier, Andy's facility of being close to Warden Norton could enable him to get more books for the prison library. Furthermore, structure in domination relation between the warden and the inmates was made use by Andy to get another privilege of putting on big posters of famous actresses at that time (Rita Hayworth and Marlyn Monroe) on his wall. This permission was granted as a barter for the favor of giving financial advice and of managing Norton's wealth gotten from money laundering and bribery. Thanks to the seemingly insignificant permission of putting on the big posters on the wall, Andy got his freedom by digging a tunnel for almost twenty years behind the posters. Moreover, Andy did not only play tricks on the structure inside prison but also on the administrative system or structure outside. Andy could create a fictive name (that is Randal Stevens) for Norton's wealth and the necessary documents (birth certificate, driving license, social security number). Thus, when he could escape from the prison, he could claim Norton's wealth and sent Norton's criminal records to a newspaper to undermine the prison structure created by Norton and put some of corruptive officers to jail. As for Norton himself, he shot his throat. This example shows how Andy's agency is limited by structure (as rules) but also how it enables him (as resources) to get his freedom and justice.

\section{CONCLUSION}

From the analysis above, it can be concluded that although Andy's agency role is very outstanding in this film, but actually Andy only reproduces the available system or structure with some changes on the part of the structure. Whatever Andy does cannot be separated from the structure of prison in the form of officers' domination toward the inmates so that some changes that Andy makes toward the prison structure are still under its frame since he still needs to get permission either from Captain Hadley or from Warden Norton. When Andy pushes too far against Norton's authority to request for having a retrial upon the information given by another inmate mentioning that the one who killed his wife and her illicit lover was a criminal called Blatch, Andy was sanctioned to be put in a solitary cell for a month and another month to give him a lesson and to give up the idea of getting the chance for a retrial. Actually Warden Norton was afraid that if Andy was free, he would reveal his money laundry and tax fraud. Although finally Andy 
managed to escape and reveal Norton's crime, but after Norton committed suicide and Hadley was under arrest, the structure in the prison will be reproduced. In this regard, time-space distantiation plays an important role as Giddens (1986) said that:

Human societies, or social systems would plainly not exist without human agency. But it is not the case that actors create social systems: they reproduce or transform them, remaking what is already made in the continuity of praxis. ... the greater the time-space distantiation of social systems - the more their institutions bite into time and space - the more resistant they are to manipulation or change by any individual agent" (p. 171).

It can also be concluded that the agency of Andy, Red, Norton, and Brooks cannot be separated from the structure. This is what Giddens said about the nature of structure itself: "Structure refers not only to rules implicated in the production and reproduction of social systems but also to resources" (p. 23). Rules constraint agents in their action, but resources enable them to make some changes. Furthermore, he also said that the interplay of agency and structure was continual (p. 362). In a word, agents cannot live outside structure, but agency is needed to make some necessary changes to enable agents to survive and to make some sense in their life as has been exemplified by the characters Andy, Red, Brooks, Captain Hadley, and Warden Norton. When they meet a deadlock, such as in the case of Norton and Brooks, they commit suicide.

\section{REFERENCES}

Bryant, C.G.A., \& Jary, D. (2003). Anthony Giddens. In G. Ritzer (Ed.), The blackwell companion to major contemporary social theorists (pp. 247273). Malden, MA: Blackwell Publishing.

Darabont, F. (Director), \& Marvin, N. (Producer). (1994). The Shawshank redemption. United States: Columbia Pictures.

Fraley, J. (2011, October 3). The Shawshank redemption (1994). Retrieved from http://thefilmspectrum.com/?p=663

Giddens, A. (1986). The constitution of society: Outline of the theory of structuration. New Ed edition. Berkeley: University of California Press.

Lamsal, M. (2012). The structuration approach of Anthony Giddens. Himalayan Journal of Sociology \& Antrhopology, $V, 111-122$.

Priyono, B. H. (2003). Anthony Giddens: Suatu pengantar. Second print. Jakarta: Kepustakaan Populer Gramedia. 